https://journal.uwgm.ac.id/index.php/abdimasmahakam

E-ISSN: 2549-5755

Januari 2020, Vol. 4 No. 01

Received: September 2019

Accepted: November2019

Published: Januari 2020

Article DOI: http://dx.doi.org/ 10.24903/jam.v4i1.766

\title{
Kelompok Ayah Pendukung ASI Dukuh Salakan Bangunjiwo Kasihan Bantul Yogyakarta
}

\author{
Luluk Rosida \\ Universitas 'Aisyiyah Yogyakarta \\ rosidalulu@gmail.com \\ Intan Mutiara Putri \\ Universitas Aisyiyah Yogyakarta \\ Intanmutiaraputri@unisayogya.ac.id
}

\begin{abstract}
Abstrak
Pemberian ASI eksklusif pada bayi bukan hanya tanggung jawab ibu. Dukungan suami, keluarga, dan masyarakat serta pihak yang terkait lainnya sangat dibutuhkan untuk meningkatkan perilaku ibu dalam memberikan ASI eksklusif kepada bayi. Keberhasilan ASI eksklusif merupakan hubungan segitiga antara ibu, anak dan suami (Simaratama, 2009). Keikutsertaan suami secara aktif dalam masa kehamilan membantu keberhasilan istri dalam mencukupi pemberian ASI untuk bayi. Peran suami turut menentukan keberhasilan ibu dalam memberikan ASI eksklusif. Hal ini karena kelancaran refleks pengeluaran ASI (let down reflek) dipengaruhi oleh keadaan emosi atau perasaan (Roesli, 2012). Permasalahan yang ditemukan selanjutnya dirumuskan bersama mitra yaitu Cakupan ASI eksklusif yang masih dibawah target, adanya ibu hamil yang berjumlah 8 orang membutuhkan dukungan terhadap persiapan pemberian ASI eksklusif, kelompok ayah yang belum mengetahui tentang perannya dalam mendukung ASI eksklusif Solusi yang sepakatibersama mitra adalah pelatihan kelompok ayah pendukung ASI.Kehadiran para ayah di tengah didalam keluarga akan memberikan dukungan dalam pemberian ASI eksklusif.
\end{abstract}

Kata Kunci: Kelompok ayah; Pendukung; Asi eksklusif.

\section{Pendahuluan}

ASI eksklusif merupakan salah satu indikator dari kesehatan balita yang dapat dilihat dri Angka Kematian Bayi (AKB) atau Infant Mortality Rate (IMR). Dampak dari kegagalan ASI eksklusif dapat mengkibatkan bayi 17 kali lebih besar mengalamai diare, 3-4 kali lebih besar terkena infeksi saluran pernafasan atas (ISPA), menurunkan resiko obesitas, kekurangan gizi, stuntingdan penyakit kronis ((Kristiyanasari, 2009)

Berdasarkan laporan World Health Organization (WHO) tahun 2016 menyebutkan bahwa cakupan ASI eksklusif masih menunjukkan rata-rata angka pemberian ASI eksklusif di dunia baru berkisar 38\%(WHO, 2016). Di Indonesia cakupan ASI eksklusif secara nasional sebesar $35,7 \%$ masih jauh dari target capaian ASI eksklusif secara global yaitu 80\% (Kemenkes, 


\section{(A) ABDIMAS \\ https://journal.uwgm.ac.id/index.php/abdimasmahakam}

E-ISSN: 2549-5755

Januari 2020, Vol. 4 No. 01

2017). Banyak faktor yang menjadi penyebab Kematian bayi AKB antara lain faktor gizi. Salah satu penyebab tidak lansung dari kematian Bayi adalah status gizi bayi yang termasuk di dalamnya adalah keberhasilan ASI. Gizi yang paling sempurna untuk bayi adalah Air susu Ibu , maka kecukupan dan keberhasilan ASi merupakan factor serius yang harius diperhatikan dalam menurunkan Angka kematian bayi. (Maryuanani, 2012)

Cakupan ASI eksklusif untuk Provinsi Daerah Istemewa Yogyakarta tahun 2017 sebesar 61,45\% (Kemenkes, 2017). Cakupan ASI eksklusif di Kabupaten Sleman sebesar 81,62\%, Kabupaten Bantul sebesar 75,06\%, Kaupaten Kulon Progo sebesar 75,11\%, Kabupaten Gunung Kidul sebesar 65,28\% dan Kota Yogyakarta sebesar 59,52\% (Dinkes, 2017)Berdasarkan profil Dinas Kesehatan Kabupaten Bantul pada tahun 2017 cakupan ASI Eksklusif di Bantul sebesar 74,27\% turun bial dibandingkan pada tahun sebelumnya sebanyak 75,06\%. Kecamatan Kasihan merupakan salah satu kecamatan yang capaiannya masih $<61 \%$.

Keberhasilan ibu dalam memberikan ASI tidak hanya bergantung pada kemampuan ibu itu sendiri namun tergantung dari beberapa faktor yang ada baik di dalam maupun di luar ibu itu sendiri. Keberhasilan ASI ekslusif tidak hanya menjadi tanggung jawab perempuan sebagai seorang ibu namun juga menjadi tanggung jawab seluruh keluarga termasuk salah satunya adalah tanggung jawab laki laki sebagai suami dan bapak. Bapak atau suami merupakan pendukung utama dalam keluarga yamng dapat memicu keberhasilan ibu dalam memberikan ASI eksklusif. (Simaratama, 2009). Suami adalah orang orang yang memiliki kedekatan ke ibu dan anak, kedekatan dan perhatian orang terdekat dalam hal ini suami bisa memicu luaran hormone oksitosin yang merupakan hormone kebahagiaan sehingga ASi lebih lancar(Roesli, 2012)

Desa Bangunjiwo terletak di bagian selatan kecamatan Kasihan Bantul, Propinsi Daerah IstimewaYogyakarta. Desa ini berjarak dari kota Yogyakarta sekitar $7 \mathrm{~km}$ dengan menyusuri Jalan Bantul, dan masuk melalui Gerbang Wisata Kasongan.Luas wilayah Bangunjiwo sebesar 1.077,78 hektar (66.80 \%) diperuntukan bagi permukiman dan perumahan penduduk sedangkan sisanya untuk sawah sebesar 322 hektare $(19.96 \%)$ dan untuk jalan sebesar 95.84 hektare (5.94 \%). Secara geografis wilayah Desa Bangunjiwo, kecamatan Kasihan, Bantul tidak diuntungkan karena sebagian besar wilayahnya adalah pegunungan.Desa Bangunjiwo berdiri tanggal 6 Desember 1946 sebagai gabungan dari desa Paitan, Sribitan, Bangen dan Kasongan. Saat ini terdiri dari 19 pedukuhan (kampung) dan 135 RT dengan jumlah penduduk yang terdaftar di buku register penduduk sebanyak 19.809 jiwa tediri dari 4.466 KK. Berdasarkan data yang didapatkan saat posyandu pada bulan Novemmber 2018 di Dusun Salakan terdapat ibu hamil sebanyak 8 orang. 


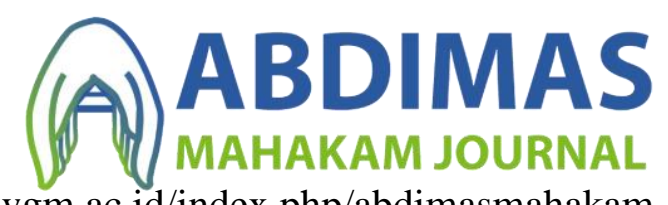

https://journal.uwgm.ac.id/index.php/abdimasmahakam

E-ISSN: 2549-5755

Januari 2020, Vol. 4 No. 01

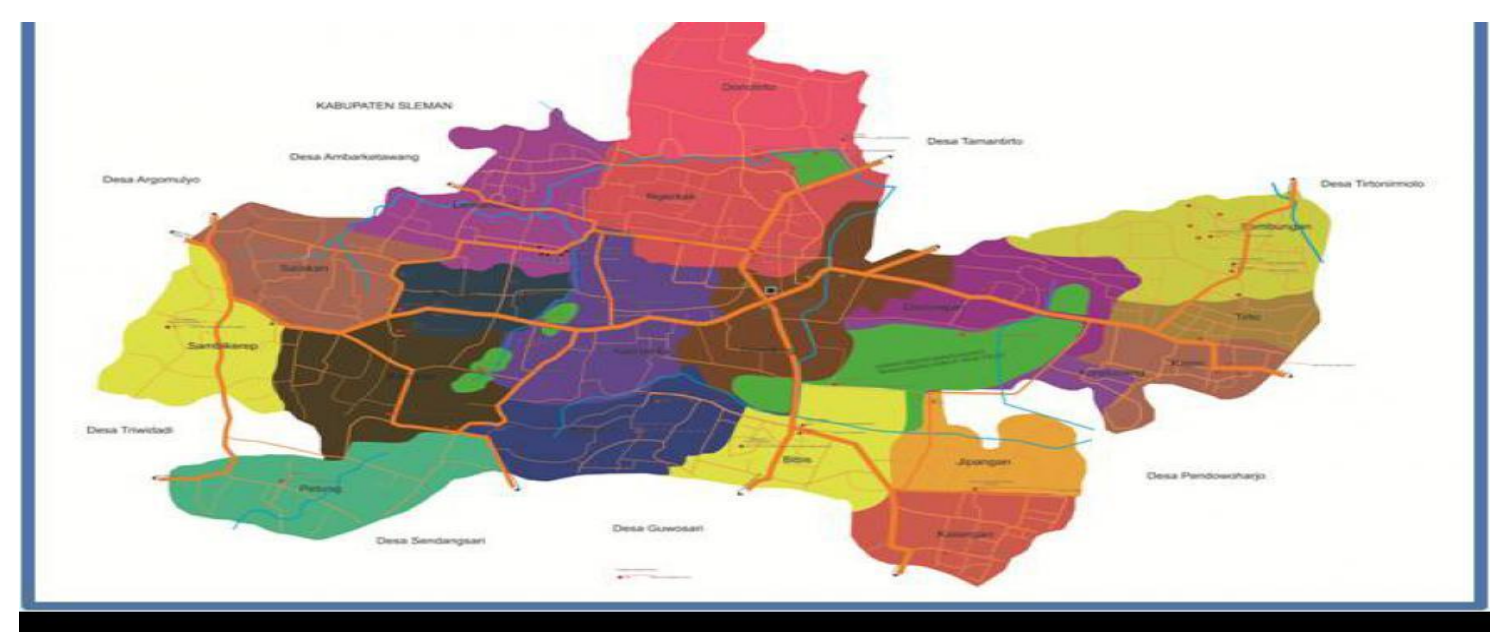

Gambar 1. Data Demografi Wilayah Bangunjiwo

\section{Metode}

Kegiatan pengabdian ini memberikan pelatihan pijat oxytocin kepada suami suami yang istrinya mempunyai bayi dan sedang menyusui ASI eksklusif. Pelaksanaan penelitian dilakukan melalui beberpa tahapan. Adapun tahap pelaksanaan kegiatan sebagai berikut: tahap 1: Assesment yaitu melakukan Pendataan terkait pengetahuan dan sikap ayah dalam medukung program ASI eksklusif dengan melakukan wawancara. Mitra berperan dalam mengumpulkan peserta dan mengisi kuesioner pretest. Tahap 2 : Planning and development Perencanaan dan persiapan terkait program KAPA. Menyusun media penyuluhan :leaflet, jadwal pelaksanaan program. Mitra berperan turut dalam merencanakan jadwal program. Ketua kader kesehatan Dusun Salakan adalah Bu Murtini menyetujui bahwa kegiatan penyuluhan akan dilaksanakan pada tanggal 9 September 2019. Tahap 3 : Implementation atau Pelaksanaan kegiatan pada tanggal 9 September 2019 di Rumah Pak Dukuh Salakan. Peserta terdiri dari bapak-bapak yang memiliki anak usia 0-12 bulan, suami yang istrinya sedang hamil dan kader kesehatan Posyandu Kaca Piring. Keseluruhan peserta berjumlah 26 orang. Tahap 4 : Evaluation Melakukan evaluasi setelah pelaksanaan program dengan cara pendataan kembali pengetahuan dan sikap ayah terhadap dukungan dalam program ASI eksklusif.

\section{Hasil dan Pembahasan}

\section{Assesment}

Kegiatan ini dilaksanakan pada saat Posyandu Balita dilaksanakan pada tanggal 16 Agustus 2019. Dilakukan wawancara pada bapak-bapak yang hadir mengantar anak dan istrinya posyandu. Dari 4 orang yang diwawancarai semua mengatakan belum pernah mengetahui tentang adanya Ayah Penudukung ASI. Mereka menganggap selama ini bahwa menyusui merupakan urusan istrinya. 


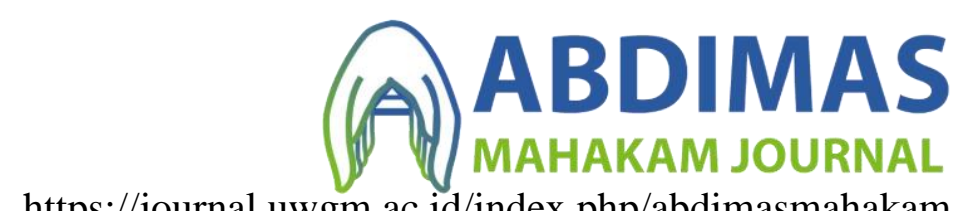

https://journal.uwgm.ac.id/index.php/abdimasmahakam

E-ISSN: 2549-5755

Januari 2020, Vol. 4 No. 01

\section{Planning anddevelopment}

kegiatan penyuluhan akan dilaksanakan pada tanggal 9 September 2019. Penyulluhan diberikan kepada kader dan bapak yang memiliki istri sedang menyusui ASi Ekslusif.

\section{Implementation}

Pelaksanaan kegiatan pada tanggal 9 September 2019 di Rumah Pak Dukuh Salakan. Peserta terdiri dari bapak-bapak yang memiliki anak usia 0-12 bulan, suami yang istrinya sedang hamil dan kader kesehatan Posyandu Kaca Piring. Keseluruhan peserta berjumlah 26 orang. Pemberian materiyang pertama tentang Program ASI Eksklusif yang disampaikan oleh disampaikan Intan Mutiara Putri, S.ST., M.Keb. Materi kedua mengenaiPeran Dukungan Ayah terhadap keberhasilan ASI Eksklusif disampaikan oleh Luluk Rosida, S.ST., M.KM. Materiketiga mengenaiTutorial Pijat Oxcytocin sebagai upaya meningkatkan produksi ASI disampaikan oleh mahasiswa.

Kegiatan ini dilakuakn secara berkelompok. Peran mitra pada tahap implementation adalah berpartisipasi dalam kegiatan penyuluhan dengan mengikuti penyuluhan secara keseluruhan. Selama kegiatan bapakbapak mengikuti secara antusias.

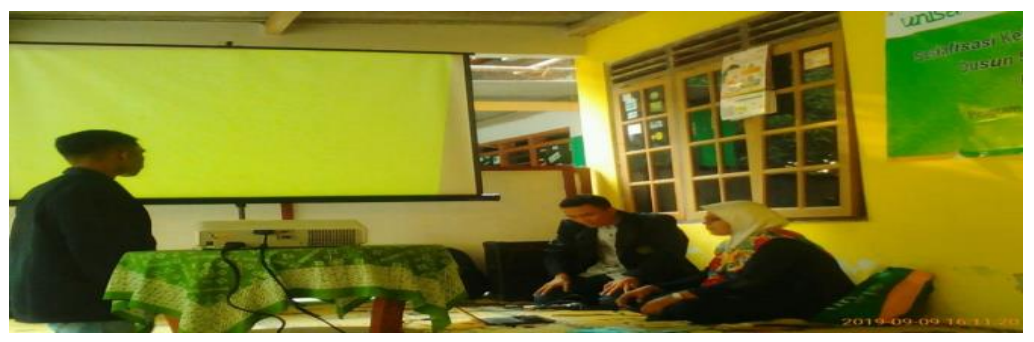

Gambar. 2 Pelaksanaan Kegiatan

\section{Evaluation}

Setelah dilaksanakan kegiatan dilakukan posttest terhadapat peningkatan pengetahuan peserta mengenai informasi ASI eksklusif dan dukungan suami terhadap pemberian ASI. Pembentukan kepengurusan KAPA Dusun Salakan Bangunjiwo Kasihan Bantul Yogyakarta dilaksanakan secara musyawarah, didapatkan hasil Ketua KAPA Bapak Basuki dan Sekretasi Bapak Sudali. Sedangkan bapak-bapak yang hadir lainnya sbegai anggota. Mitra berperan dalam diskusi pembentukan pengurus KAPA dengan dukungan penuh dari kader kesehatan Posyandu Kaca Piring Dusun Salakan. 


\section{(A) ABDIMAS}

https://journal.uwgm.ac.id/index.php/abdimasmahakam

E-ISSN: 2549-5755

Januari 2020, Vol. 4 No. 01

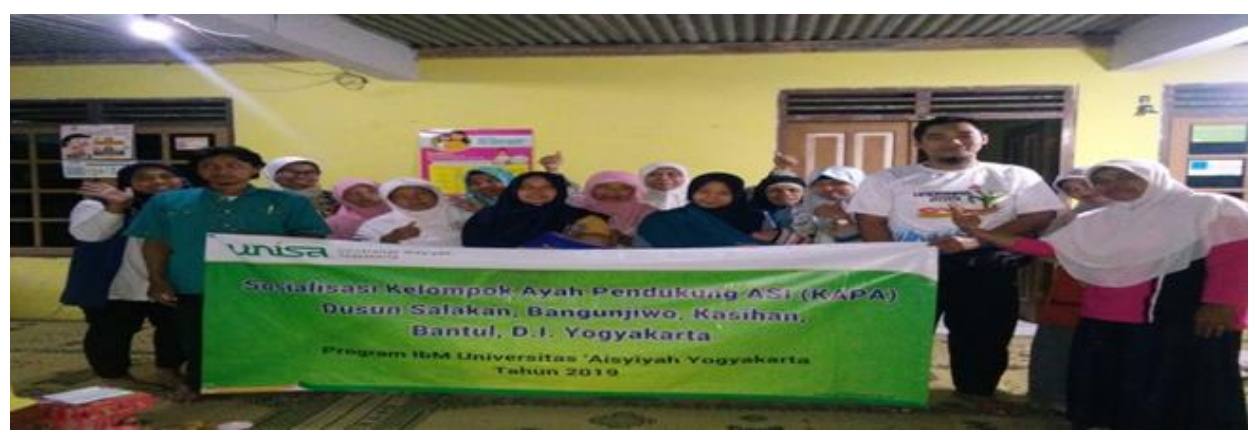

Gambar. 3 bersama warga desa

\section{Simpulan dan rekomendasi}

Pelaksanaan kegiatan pengabdian dengan tema KAPA (Kelompok Ayah Pendukung ASI ini berjalan dengan lancer. Partisipasi peserat aktif dan mendapatkan dukungan dari kader kesehatan Posyandu Bunga Kaca Piring Dusun Salakan. Luaran kegiatan ini terbentuknya Ketua dan sekretasi KAPA Posyandu Bunga Kaca Piring Dusun Salakan. Rekomendasi pelatihan dan kegiatan ini diharapkan menjadi kegiatan rutin d Posyandu Kaca Piring Dusun Salakan. 
https://journal.uwgm.ac.id/index.php/abdimasmahakam

E-ISSN: 2549-5755

Januari 2020, Vol. 4 No. 01

\section{Daftar Pustaka}

Dinkes, D., 2017. Profil Kesehatan Kota Yogyakarta, Yogyakarta: Dinkes Kota Yogyakarta .

Kemenkes, R., 2017. Pedoman Surveilans Gizi Indonesia. [Online] Available at: http://gizi.depkes.go.id/wpcontent/uploads/2012/06/NewBukuSurveilans.pdf [Accessed 1 November 2018].

Kristiyanasari, W., 2009. ASI, Menyusui dan Sadari. Yogyakarta: Nuha Medika.

Maryuanani, A., 2012. Inisiasi Menyusui Dini, ASI Eksklusif dan Manajemen Laktasi. Jakarta : CV Trans Info Medika.

Meilia, D. \& Putri, I. M., 2018. Hubungan Dukungan Suami dengan Perilaku Pemberian ASI Eksklusif di Puskesmas Umbulharjo I Yogyakarta. [Online] Available at: http://www.digilibunisa.com [Accessed 1 November 2018].

Roesli, U., 2012. Mengenal ASI Eksklusif. Jakarta: PT. Pustaka Pembangunan Swadaya Nusantara.

Simaratama, 2009. Mempererat Bonding Antara Bayi dan Ayahnya. [Online] Available at: http://cybermed.cbn.net.id. [Accessed 3 November 2018].

WHO, 2016. Steps To sucessful Breastfeeding During Post Delivery. [Online] Available at: $\quad$ www.who.it/pmch/media/news/2016who/en. [Accessed 12 November 2018]. 